J. Clin. Chem. Clin. Biochem.

Vol. 18, 1980, pp. 407-411

\title{
Colorimetric Determination of Glycine Conjugates of Bile Acids
}

\author{
By M. Ikeda, N. Nanba, S. Hayakawa and S. Ohmori
}

Faculty of Pharmaceutical Sciences, Okayama University, Okayama 700, Tsushima-Naka-1, Japan

(Received September 11, 1979/March 4, 1980)

Summary: A simple assay was developed for the determination of glycine-conjugated bile acids. Samples containing the glycine-conjugated bile acids in the range from 15 to $250 \mathrm{nmol}$ were acidified with $\mathrm{HCl}$, and extracted with ethyl acetate containing ethanol $(50 \mathrm{ml} / \mathrm{l})$. An aliquot of the organic phase was evaporated to dryness, and the dried residue was treated to develop the color by the addition of acetic anhydride, pyridine and a trace amount of phosphoric acid. The absorbance was measured at 429 or $456 \mathrm{~nm}$ after the reaction at $50^{\circ} \mathrm{C}$ for $2 \mathrm{~h}$. Color development did not occur with unconjugated and taurine-conjugated bile acids. Beer's law was obeyed from 12.5 to $200 \mathrm{nmol}$ in a cuvette. The recovery of the conjugates from the rabbit gall bladder bile and liver homogenate was satisfactory. This method requires no hydrolysis step and is applicable to the determination of glycine-conjugated bile acids in bile, duodenal aspirate and liver homogenate.

\section{Kolorimetrische Bestimmung von Glycin-Konjugaten von Gallensäuren}

Zusammenfassung: Eine einfache Bestimmungsmethode für die mit Glycin konjugierten Gallensäuren wurde entwickelt. Die die Glycin-konjugierten Gallensäuren im Bereich von 15 bis $250 \mathrm{nmol}$ enthaltenden Proben wurden mit $\mathrm{HCl}$ angesäuert und mit $50 \mathrm{ml} / 1$ Ethanol enthaltendem Ethylacetat extrahiert. Ein Aliquot der organischen Phase wurde im Vakuum zur Trockene gebracht, und durch Zugabe von Acetanhydrid, Pyridin und einer Spur Phosphorsäure zu dem getrockneten Rückstand entwickelte sich eine Färbung. Die Absorption bei 429 oder $456 \mathrm{~nm}$ wurde nach 2stündiger Reaktion bei $50^{\circ} \mathrm{C}$ bestimmt. Bei freien oder Taurin-konjugierten Gallensäuren trat keine Farbentwicklung ein. Im Bereich von 12,5 bis $200 \mathrm{nmol}$ pro Küvette ist die Methode in guter Úbereinstimmung mit dem Beer'schen Gesetz. Die Wiederfindung der Konjugate in Kaninchengalle und -leberhomogenat war befriedigend. Die Methode benötigt keinen Hydrolyseschritt und ist zur Messung der Glycin-konjugierten Gallensäuren in Galle, Duodenalaspirat und Leberhomogenat geeignet.

\section{Introduction}

Several methods are available for the joint or separate determination of glycine and taurine conjugates of bile acids in biological samples. Levin et al. (1) reported the spectrophotometric determination of both conjugates after their separation and purification. The color reaction for the conjugates was based on either the cholic acid or deoxycholic acid moiety. Tiselius \& Heuman (2) reported another spectrometric method for total glycineand taurine-conjugates. They separated glycine and taurine from the alkaline hydrolysate of bile by chromatography on a column of a strongly acidic ion exchanger and then estimated them by a well-known ninhydrin reaction. In addition, many methods such as radioimmunoassay (3-7), thin-layer chromatographic method (8-10), liquid chromatographic method (11-15), enzymatic method $(16,17)$ and enzymeimmunoassay (18) have been reported. Recently, we established a simple method for the colorimetric determination of hippuric acid in biological samples (19) and devised a specific method for the determination of glycine (20). In the latter method, glycine was first converted to hippuric acid by benzoylation. In the course of these studies, we noticed that peptides having a glycine residue at their $\mathrm{C}$-terminals show a similar color reaction. We therefore applied the color reaction to quantitation of glutathione and glycine-conjugated bile acids. In the present paper, a method is described for the determination of glycine-conjugated bile acids, which is applicable to bile, duodenal aspirate and liver homogenate. 


\section{Materials and Methods}

\section{Reagents and Instruments}

Glycocholic acid, glycodeoxycholic acid, sodium glycochenodeoxycholate, glycodehydrocholic, acid, gly colithocholic acid, $\mathrm{N}-3 \alpha, 12 \alpha$-dihydroxy-7-oxo-5 $\beta$-cholan-24-oylglycine, $\mathrm{N}-3 \alpha-$ hydroxy-7, 12-dioxo-5 $\beta$-cholan-24-oylglycine, glycohyodeoxycholic acid and sodium glycohyocholate were prepared by the method of Norman (21) or its modification. All of these samples moved as a single spot on thin-layer chromatography (silica gel; chloroform-methanol-acetic acid-water, $65 \mathrm{ml}+24 \mathrm{ml}+15 \mathrm{ml}$ $+9 \mathrm{ml}$ ). All other reagents (analytical grade) were purchased from Wako Pure Chemicals Industries Ltd. (Osaka). Human duodenal aspirates were supplied by Dr. H. Kono and M. Aoyama of the Medical School of this University. Visible absorption spectra were made on a Hitachi 124 spectrophotometer. Evaporation of organic solvents under reduced pressure and mixingor extraction-procedures were carried out as described in our previous paper (20).

\section{Methods}

Determination of glycine-conjugated bile acids in aqueous solution

Each aqueous solution of glycine-conjugated bile acids containing up to $250 \mathrm{nmol}(0.5 \mathrm{ml})$ was acidified with $6 \mathrm{~mol} / 1 \mathrm{HCl}$ $(50 \mu 1)$, and extracted with $2.5 \mathrm{ml}$ of ethyl acetate containing ethanol $(50 \mathrm{ml} / \mathrm{l})$. An aliquot $(2.0 \mathrm{ml})$ of the ethyl acetate layer was transferred to a $20-\mathrm{ml}$ test tube and evaporated to dryness under reduced pressure.

The quantity of glycine-conjugates in the dried residues was determined according to our previous reports $(19,20)$ with a slight modification as given below. Acetic anhydride $(1.0 \mathrm{ml})$, pyridine $(2.0 \mathrm{ml})$ and $430 \mathrm{~g} / \mathrm{kg}$ phosphoric acid $(10 \mu \mathrm{l})$ were added to the dried residue in turn, and the solution was vigorously mixed. $p$-Dimethylaminobenzaldehyde, which was used in our.previous reports, was omitted from these chromogens in the present procedure. After color development at $50^{\circ} \mathrm{C}$ for 2 hours, the absorbance was measured at $429 \mathrm{~nm}$ against a blank solution containing acetic anhydride, pyridine and phosphoric acid.

\section{Determination of glycine-conjugates in bile or duodenal aspirate}

Rabbit gall bladder bile was diluted 1000 times with water, and human duodenal aspirate 10 to 100 times. An aliquot $(0.5 \mathrm{ml})$ of these solutions was added to $300 \mathrm{~g} / \mathrm{kg} \mathrm{H}_{2} \mathrm{O}_{2}(50 \mu \mathrm{l})$, and, if necessary, the mixture was incubated at $40^{\circ} \mathrm{C}$ until color due to bile pigments disappeared. These diluted sample solutions were acidified with $6 \mathrm{~mol} / 1 \mathrm{HCl}(50 \mu \mathrm{l})$ and treated as described in the previous section.

\section{Determination of glycine-conjugates in liver homogenate}

Rabbit liver $(10 \mathrm{~g})$ was homogenized in $90 \mathrm{ml}$ of a medium containing $0.25 \mathrm{~mol} / 1$ sucrose, $3 \mathrm{mmol} / 1$ potassium phosphate buffer ( $\mathrm{pH} 7.4$ ) and $0.1 \mathrm{mmol} / 1$ EDTA using a Potter-Elvejhem homogenizer equipped with a Teflon pestle. The homogenate was centrifuged at $700 \mathrm{~g}$ for $10 \mathrm{~min}$. The supernatant $(0.5 \mathrm{ml})$ was mixed with $6 \mathrm{~mol} / 1 \mathrm{HCl}(50 \mu \mathrm{l})$ and ethyl acetate $(2.5 \mathrm{ml})$ containing ethanol $(50 \mathrm{ml} / \mathrm{l})$. After centrifugation at $1000 \mathrm{~g}$ for $5 \mathrm{~min}$, an aliquot $(2.0 \mathrm{ml})$ of the ethyl acetate layer was evaporated to dryness under reduced pressure and the color was developed as described above.

\section{Determination of glycine in bile hydrolysate}

Rabbit bile and human duodenal aspirates were hydrolyzed according to the principle of Tiselius \& Heuman (2) as follows. One $\mathrm{ml}$ of human duodenal aspirates or rabbit gall bladder bile, which had previously been diluted 10 times with water, was mixed with $4 \mathrm{ml}$ of methanol-acetone mixture $(2 \mathrm{ml}+2 \mathrm{ml}$ ). After standing the mixture at $37^{\circ} \mathrm{C}$ for $10 \mathrm{~min}$, it was centrifuged at $1000 \mathrm{~g}$ for $5 \mathrm{~min}$. The precipitate was resuspended in $2 \mathrm{ml}$ of the methanol-acetone mixture and centrifuged again. The supernatant and the washings were combined, evaporated to dryness under reduced pressure, and the residue was dissolved in one $\mathrm{ml}$ of methanol.
In the case of human duodenal aspirate, which contains more concomitants than the rabbit bile, glycine-conjugates were further purified by treating with an ion exchanger. An aliquot $(0.25 \mathrm{ml})$ of the methanol solution obtained above was added to $0.8 \mathrm{~g}$ wet weight of Dowex $50 \mathrm{~W} \times 8\left(100-200 \mathrm{mesh}, \mathrm{H}^{+}\right.$ form), and the mixture was vigorously stirred with a Vortexmixer. After centrifugation at $1000 \mathrm{~g}$ for a minute, the supernatant was transferred to a $20-\mathrm{ml}$ test tube. The resin was washed with two separate $2 \mathrm{ml}$ portions of methanol. The supernatant and the washings were combined, evaporated to dryness under reduced pressure, and the residue was dissolved in the original volume $(0.25 \mathrm{ml})$ of $0.05 \mathrm{~mol} / 1 \mathrm{NaOH}$. An aliquot $(0.1 \mathrm{ml})$ of the rabbit bile treated with methanol-acetone or the further purified human duodenal aspirate described above was placed in a $5 \mathrm{ml}$ ampule, to which $2 \mathrm{~mol} / 1 \mathrm{NaOH}$ $(1.2 \mathrm{ml})$ was added. After sealing the ampule, it was heated at $120^{\circ} \mathrm{C}$ for $5 \mathrm{~h}$ in an electric oven. $2 \mathrm{~mol} / 1 \mathrm{NaOH}$ was added to an aliquot $(0.1 \mathrm{ml}$ for the rabbit bladder bile or 0.1 to $1.0 \mathrm{ml}$ for human duodenal aspirates) of the hydrolysate to make a total volume of $1.0 \mathrm{ml}$ in a $20-\mathrm{ml}$ test tube, and benzoyl chloride $(50 \mu \mathrm{l})$ was added. The mixture was treated according to our previous report (20), except that $6 \mathrm{~mol} / \mathrm{l} \mathrm{HCl}(0.4 \mathrm{ml})$ was used for the acidification of the solution after benzoylation of glycine.

\section{Results}

\section{Absorption spectrà}

The absorption spectra of the respective colored solutions obtained from authentic glycocholic acid and rabbit bladder bile are shown in figure 1 . Both spectra gave a similar shape. The shape of the spectra of nine kinds of glycine-conjugates tested were essentially identical, showing the maxima at 405,429 and $456 \mathrm{~nm}$.

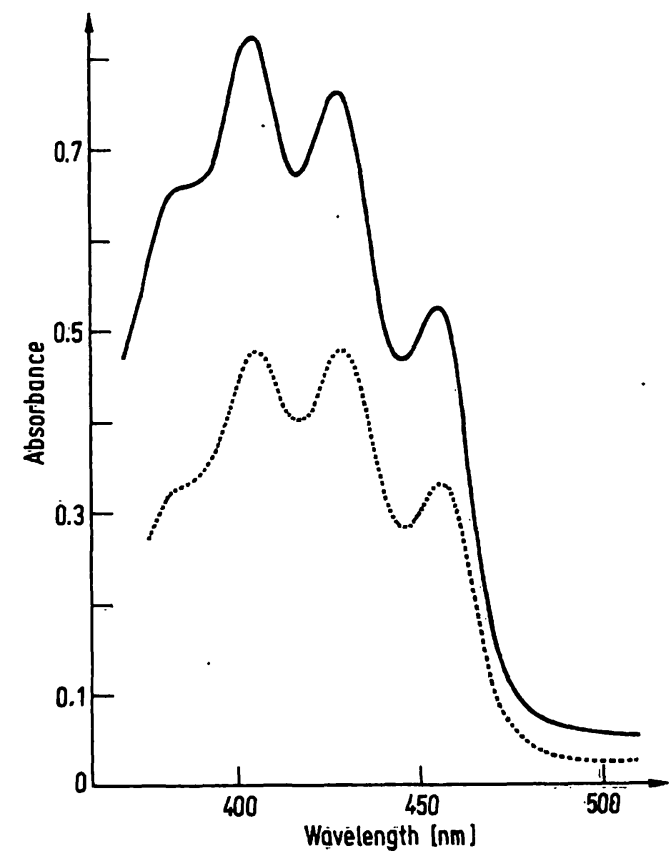

Fig. 1. Absorption spectra of the colored solution from glycocholic acid (-) and the rabbit bile (....). Glycocholic acid (150 nmol/cuvette) or $0.5 \mu$ of the rabbit gall bladder bile was reacted with acetic anhydride, pyridine and a cataly tic amount of phosphoric acid. 


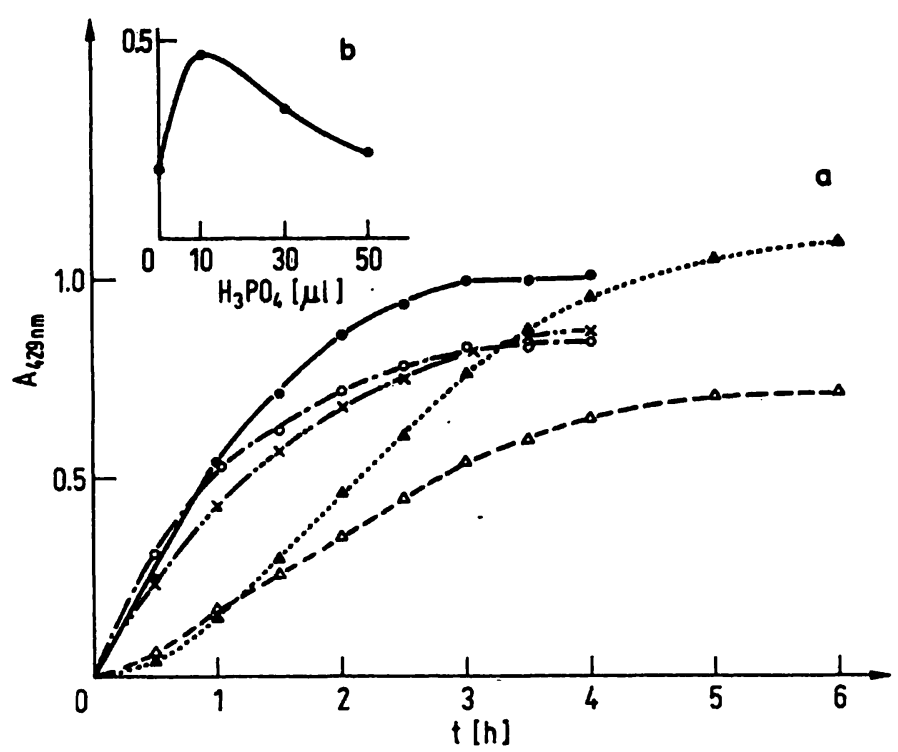

Fig. 2. Effect of the reaction time and the presence of several acids on color development.

Color was developed at $50^{\circ} \mathrm{C}$ using glycocholic acid (200 nmol/cuvette in fig. $2 \mathrm{a}, 100 \mathrm{nmol}$ in fig. 2b) in the presence or the absence of several acids.

In fig. 2a, the time course of color development is shown in the presence of $430 \mathrm{~g} / \mathrm{kg}$ phosphoric acid $(10 \mu \mathrm{l}$, $\bullet-\bullet)$, concentrated sulfuric acid $(0--0)$, concentrated hydrochloric acid $(x-\cdots-x)$, glacial acetic acid $(\Delta . . . . . .4)$, and in the absence of the acids $(\Delta--\Delta)$.

Fig. $2 b$ shows the effect of the amount of phosphoric acid on the color development at $50^{\circ} \mathrm{C}$ for 2 hours.

\section{Conditions for color development}

Figure 2a shows the effect of the reaction time and several acids on the color development from glycocholic acid at $50^{\circ} \mathrm{C}$. Data indicate that phosphoric acid was most effective for increasing the absorbance, and its optimal amount was $10 \mu \mathrm{l}$ of $430 \mathrm{~g} / \mathrm{kg}$ phosphoric acid in $3.01 \mathrm{ml}$ of the reaction mixture (fig. 2b). From these results, the reaction conditions of $50^{\circ} \mathrm{C}$ for $2 \mathrm{~h}$ in the presence of $430 \mathrm{~g} / \mathrm{kg}$ phosphoric acid $(10 \mu \mathrm{l})$ were chosen and adopted in subsequent experiments. Similar results were obtained with other glycine-conjugates.

\section{Standard curve and sensitivity}

The standard curve for glycocholic acid is shown in figure 3 as a representative glycine-conjugate. The curve is linear up to 200 nmol in a cuvette, and as little as 12.5 nmol can be measured by the present procedure. The molar abșorption coefficients for all of the glycineconjugates tested were calculated as $1.56 \pm 0.05(n=3)$ for glycocholic acid, $1.48 \pm 0.10(n=6)$ for glycodeoxycholic acid, $1.41 \pm 0.08(n=4)$ for glycochenodeoxycholic acid, 1.56 for glycodehydrocholic acid,

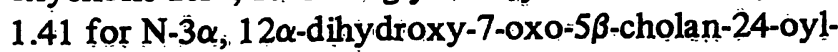

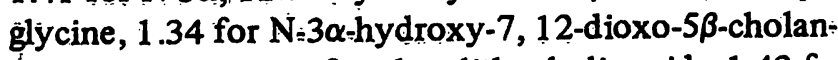
24-oyl-glycine, 1.41 for glycolithocholic acid, 1.43 for glycohyodeoxycholic acid and $1.45 \times 10^{4} 1 \cdot \mathrm{mol}^{-1}$. $\mathrm{cm}^{-1}$ for glycohyocholic acid. Data indicate that a

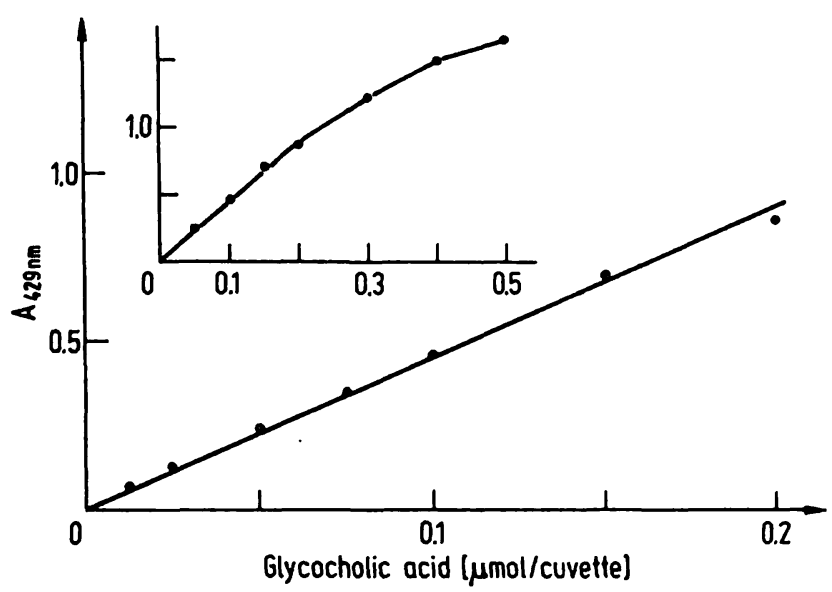

Fig. 3. Standard curve of glycocholic acid.

Varying amounts of glycocholic acid were treated as described under Experimental, and the absorbance was imeasured at $429 \mathrm{~nm}$ after reaction at $50^{\circ} \mathrm{C}$ for 2 hours.

minor modification of steroid moiety has no effect on the culor development. The mean molar absorption coefficient obtained from the above data was $1.45 \pm$ $0.07 \times 10^{4} 1 \cdot \mathrm{mol}^{-1} \cdot \mathrm{cm}^{-1}$.

\section{Recovery tests}

In order to apply the present procedure to biological samples, recovery tests were carried out. Varying amounts of glycocholic acid, glycodeoxycholic acid or glycochenodeoxycholic acid were added to the rabbit bile or to liver homogenate, and the amount of each glycine-conjugate was measured. Table 1 shows that the recoveries of the conjugates from rabbit bile were 94.0 to $99.3 \%$ (mean \pm SD; $95.9 \pm 2.9$ ) for glycocholic acid, 97.3 to $106.0 \%(101.8 \pm 4.4)$ for glycodeoxycholic acid, and 93.5 to $96.7 \%(95.4 \pm 1.7)$ for glycochenode-

Tab. 1. Recovery of glycine conjugate added to rabbit bile ${ }^{1}$ ).

\begin{tabular}{|c|c|c|c|c|}
\hline $\begin{array}{l}\text { Species of } \\
\text { gly cine conjugates }\end{array}$ & $\begin{array}{l}\text { Glycine } \\
\text { con- } \\
\text { jugate } \\
\text { added } \\
(\mathrm{mmol} / \mathrm{l})\end{array}$ & $\begin{array}{l}\text { Glycine } \\
\text { con- } \\
\text { jugate } \\
\text { found } \\
\text { (mmol/l) }\end{array}$ & Recovery & Mean \pm SD \\
\hline Glycocholic acid & $\begin{array}{r}0 \\
100 \\
200 \\
300\end{array}$ & $\begin{array}{l}268 \\
362 \\
457 \\
566\end{array}$ & $\begin{array}{l}94.0 \\
94.5 \\
99.3\end{array}$ & $95.9 \pm 2.9$ \\
\hline $\begin{array}{l}\text { Glycodeoxycholic } \\
\text { acid }\end{array}$ & $\begin{array}{r}0 \\
100 \\
200 \\
300\end{array}$ & $\begin{array}{l}245 \\
351 \\
449 \\
537\end{array}$ & $\begin{array}{r}106.0 \\
102.0 \\
97.3\end{array}$ & $101.8 \pm 4.4$ \\
\hline $\begin{array}{l}\text { Glycocheno- } \\
\text { deoxycholic acid }\end{array}$ & $\begin{array}{r}0 \\
100 \\
200 \\
300 \\
\end{array}$ & $\begin{array}{l}265 \\
361 \\
452 \\
555 \\
\end{array}$ & $\begin{array}{l}96.0 \\
93.5 \\
96.7 \\
\end{array}$ & $99.4 \pm 7.4$ \\
\hline
\end{tabular}

1) Varying amounts of each glycine conjugate were added to rabbit bile, and each was measured by the procedure described under Experimental. Each value is the mean from duplicate determinations. 
Tab. 2. Recovery of gly cine conjugate added to rabbit liver homogenate ${ }^{\mathrm{l}}$ ).

\begin{tabular}{|c|c|c|c|c|}
\hline \multirow{2}{*}{$\begin{array}{l}\text { Species of } \\
\text { glycine conjugates }\end{array}$} & Glycine & Glycine & Recovery & \multirow[b]{2}{*}{ Mean \pm SD } \\
\hline & $(\mathrm{mmol} / \mathrm{l})$ & $(\mathrm{mmol} / \mathrm{l})$ & $\%$ & \\
\hline Glycocholic acid & $\begin{array}{r}0 \\
250 \\
500 \\
750 \\
1000\end{array}$ & $\begin{array}{r}108 \\
380 \\
586 \\
802 \\
1020\end{array}$ & $\begin{array}{r}108.4 \\
95.4 \\
93.7 \\
91.1\end{array}$ & $97.2 \pm 7.7$ \\
\hline $\begin{array}{l}\text { Gly codeoxycholic } \\
\text { acid }\end{array}$ & $\begin{array}{r}0 \\
250 \\
500 \\
750 \\
1000\end{array}$ & $\begin{array}{r}90 \\
316 \\
572 \\
836 \\
1056\end{array}$ & $\begin{array}{l}90.7 \\
96.5 \\
99.5 \\
96.7\end{array}$ & $95.0 \pm 3.7$ \\
\hline $\begin{array}{l}\text { Glycocheno- } \\
\text { deoxycholic acid }\end{array}$ & $\begin{array}{r}0 \\
250 \\
500 \\
750 \\
1000\end{array}$ & $\begin{array}{r}104 \\
340 \\
526 \\
766 \\
1154\end{array}$ & $\begin{array}{l}94.4 \\
84.4 \\
88.3 \\
88.6\end{array}$ & $" 88.9 \div 4.1$ \\
\hline
\end{tabular}

1) Varying amounts of each glycine conjugate were added to the $700 \mathrm{~g}$ supernatant fraction of the rabbit liver, and each was measured by the procedure described under Experimental. Each value is the mean from duplicate determinations.

oxycholic acid. Table 2 shows that the conjugates added to rabbit liver homogenate were recovered in the range from 91.1 to $108.4 \%(97.2 \pm 7.7)$ for glycocholic acid, 90.7 to $99.5 \%(95.0 \pm 3.7)$ for glycodeoxycholic acid or 84.5 to $94.0 \%(88.8 \pm 3.9)$ for glycochenodeoxycholic acid.

Comparison of the results of the present method with those of the method based on the determination of glycine liberated from conjugates through hydrolysis.

The analytical values of total glycine-conjugates in the rabbit bile and thirteen human duodenal aspirates were obtained by the present method and by measuring glycine after hydrolysis, and summarized in table 3. Values from the two methods are in good agreement. Table 3 also demonstrates that there is no significant difference among the analytical values obtained from untreated, acetone-methanol-treated and Dowex-treated samples.

\section{Discussion}

Glycocholate, taurocholate, glycodeoxycholate, taurodeoxycholate, glycochenodeoxycholate and taurochenodeoxycholate are actually present in human bile. The ratio of glycine- to taurine-conjugated bile acids ( $G / T$ ratio) for duodenal aspirates from 42 volunteers was $1.81 \pm 0.15$ and that for gall bladder bile in the 27 surgical patients was $2.44 \pm 0.28$ (22). The $\mathrm{G} / \mathrm{T}$ ratio in bile was altered in various disease states $(23-25)$. On the other hand, biochemical investigations concerning the glycine conjugation have been published $(26-28)$. In
Tab. 3. Comparison of the results of the present method with those of the method based on the determination of glycine after hydrolysis of conjugates.

\begin{tabular}{lllll}
\hline Species & $\begin{array}{l}\text { Glycine conjugate }{ }^{1} \text { ) } \\
\text { found } \\
\text { (mmol/1) }\end{array}$ & & $\begin{array}{l}\text { Glycine }{ }^{2} \text { ) } \\
\text { found } \\
\text { (mmol/1) } \\
\text { Downol- }\end{array}$ \\
& Untreated & $\begin{array}{l}\text { Methex } \\
\text { acetone } \\
\text { treated }\end{array}$ & treated & treated \\
\hline Rabbit bile & 286.6 & 266.0 & 248.1 & 248.6 \\
Human & 23.2 & 26.4 & 21.3 & 20.6 \\
duodenal & 17.6 & 16.4 & 16.6 & 13.7 \\
aspirate & 28.0 & 28.6 & 29.8 & 29.4 \\
& 26.4 & 28.6 & 23.8 & 22.7 \\
& 33.0 & 33.0 & 28.3 & 28.6 \\
& 24.3 & 25.4 & 25.8 & 25.1 \\
& 7.1 & 6.4 & 7.5. & 6.7 \\
& 33.5 & 33.0 & 31.6 & 36.1 \\
& 19.0 & 24.8 & 16.0 & 19.7 \\
& 1.21 & 1.78 & 2.08 & 1.64 \\
& 1.44 & 1.18 & 1.44 & 1.22 \\
& 1.40 & 2.07 & 2.02 & 1.53 \\
& 0.66 & 0.59 & 0.53 & 0.53 \\
\hline
\end{tabular}

Each value is the mean from duplicate determinations.

1) Glycine conjugates in bile or human duodenal aspirates were assayed with or without pretreatments according to the present procedure under Experimental.

2) Glycine hydrolyzed from glycine-conjugated bile acids was assayed according to our previous report (20) after the purification of bile or duodenal aspirates ușing a strongly acidic ion exchanger (Dowex $50 \mathrm{~W} \times 8$ ) as described under Experimental.

order to determine total glycine-conjugates in bile, or a glycine-conjugate in experiments in vitro, a simple assay for glycine-conjugates is required. The spectrophotometric methods for determination of total glycine-conjugates of bile acids were reported by Levin et al. (1), and by Tiselius \& Heuman (2). However, in the former method, repeated extraction procedures are required for the separation of glycine-conjugates, and the latter method involves a column chromatography and hydrolysis step. In contrast, the present method has the advantage of having no separation and purification step as demonstrated in table 3 . The presence of glutathione and other glycine-conjugated compounds than glycineconjugated bile acids, which give a positive color reaction, have been reported $(29,30)$. Glutathione, however, does not disturb the color development in our procedure, since it cannot be extracted with ethyl acetate. The interference by the other glycine-conjugates in the present assay seems to be negligible, because they appear to be scarcely present and even if they are present, their amounts are relatively much smaller than glycine-conjugated bile acids (30).

On the basis of the results of recovery tests (table 1 and 2) and the similarity of the molar absorption coèfficients of all kinds of glycine-conjugated bile acids tested, the present method should be applicable to clinical tests. Furthermore, this method may find a use in in vitro studies of glycine-conjugated bile acids. 
We have been studying the mechanism of the color reaction specific for glycine residues since the determination of hippuric acid with acetic anhydride and pyridine was reported. In the present studies, we noticed that the presence of catalytic amount of phosphoric acid promoted the color development from glycine-conjugated bile acids, while $p$-dimethylamino-benzaldehyde gave no effect. The mechanism of the reaction, especially the problem of the requirement for the catalytic amount of phosphoric acid, is under investigation, and will be reported in the near future.

\section{Acknowledgement}

We dedicate this little paper to the late Prof. F. Lynen, who was a teacher of one of the authors.

\section{References}

1. Levin, S. J., Johnston, C. G. \& Boyle, A. J. (1961), Anal. Chem. 33, 1407-1411.

2. Tiselius, H. G. \& Heuman, R. (1978), Clin. Chim. Acta 83, 49-53.

3. Dermers, L. M. \& Hepner, G. W. (1976), Clin. Chem. 22, 602-606.

4. Dermers, L. M. \& Hepner, G. W. (1976), Am. J. Clin. Pathol. $66,831-839$.

5. Spenney, J. G., Johnston, B. J., Hirschowitz, B. I., Mihas, A. A. \& Gibson, R. (1977), Gastroenterology 72, 305-311.

6. Mihas, A. A., Spenney, J. G., Hirschowitz, B. I. \& Gibson, R. G. (1977), Clin. Chim. Acta 76, 389-397.

7. Mäentausta, O. and Jänne, O. (1979), Clin. Chem. 25, 264268.

8. Ikawa, S. \& Goto, M. (1975), J. Chromatogr. 114, 237-243.

9. Chavez, M. N. \& Krone, C. L. (1976), J. Lipid. Res. 17, 545-547.

10. Batta, A. K., Aalen, G. \& Shefer, S. (1979), J. Chromatogr. $168,557-561$.

11. Parris, N. A. (1977), J. Chromatogr. 133, 273-279.

12. Shimada, K., Hasegawa, M., Goto, J. \& Nambara, T. (1978), J. Chromatogr. 152, 431-436.

13. Goto, J., Hasegawa, M., Kato, H. \& Nambara, T. (1978), Clin. Chim. Acta 87, 141-147.

14. Shaw, R., Smith, A. \& Elliot, W. H. (1978), Anal. Biochem. $86,450-456$.

15. Maruyama, K., Tanimura, H. \& Hikasa, Y. (1980), Clin. Chim. Acta 100, 47-54.
16. Bruusgaard, A. (1970), Clin. Chim. Acta 28, 495-504.

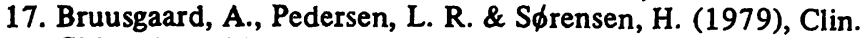
Chim. Acta 93, 1-8.

18. Baqir, Y. A., Ross, P. E. \& Bouchier, I. A. D. (1979), Anal. Biochem. 93, 361-365.

19. Ohmori, S., Ikeda, M., Kira, S. \& Ogata, M. (1977), Anal. Chem. 49, 1494-1496.

20. Ohmori, S., Ikeda, M., Watanabe, Y. \& Hirota, K. (1978), Anal. Biochem. 90, 662-670.

21. Norman, A. (1955), Ark. Kemi 8, 331-342.

22. Dam, H., Kruse, I., Prange, I., Kallenhauge, H. E., Frenger, H. J. \& Jensen, M. K. (1971), Z. Ernähr. 10, 160-177.

23. Garbutt, J. T., Heaton, K. W., Lack, L. \& Tyor, M. P. (1969), Gastroenterology 56, 711-720.

24. Abaurre, R., Gordon, S. G., Mann, J. G. \& Kern, F. (1969), Gastroenterology 57, 679-688.

25. Bruusgaard, A. \& Thuysen, E. H. (1970), Acta Med. Scand. $188,547-548$.

26. Ekdahl, P. \& Gloor, U. (1958), Acta Chir. Scand. 114, 459-460.

27. Vessey, D. A., Crissey, M. H. \& Zakin, D. (1977), Biochem. J. $163,181-183$.

28. Killenberg, P. G. \& Jordan, J. T. (1978), J. Biol. Chem. 253, $1005-1010$.

29. Sies, H., Koch, O. R., Martino, E. \& Bouveris, A. (1979), FEBS Lett. 103, 287-290.

30. Abou-El-Makarem, M. M., Millburn, P., Smith, R. L. \& Williams, R. T. (1967), Biochem. J. 105, 1269-1274.

Prof. Dr. Shinji Ohmori

Faculty of Pharmaceutical Sciences Okayama University

Okayama 700 Tsushima-Naka-1 Japạn 
. 